\title{
EMPIRICAL ANALYSIS AND ESTIMATES OF THE IMPACT OF THE EU STRUCTURAL FUNDS ABSORPTION IN COUNTRIES OF CENTRAL AND EASTERN EUROPE
}

\author{
I. Paliova* \\ $\mathrm{PhD}$ student, Economic Research Institute of Bulgarian Academy of Science, Sofia, Bulgaria
}

\begin{abstract}
The development of the economies of the Central and Eastern Europe (CEE) with the support of the European Structural Funds aims to help the countries to carry out the structural transformation and to increase the efficiency of their economies as a basis for long-term economic growth. Estimates of the fiscal impact of the European Structural Funds on aggregate demand for each country through the approach and assumptions of Rosenberg and Sierhe (2007) on the crowding out effect of EU funds on aggregate activity demonstrate their role as a fiscal stimulus for aggregate economic activity. Estimates justify that the impact of European funds on economic growth may reach between $1.5 \%$ and $3 \%$ of GDP above the baseline scenario, depending on the degree of substitution of European funded and nationally funded projects. EU funds can increase growth, but only if supported by long-term national policies and priorities to ensure economic and social cohesion and achievement of the average European standards.
\end{abstract}

Key words: Bulgaria, Central and Eastern Europe, EU structural funds, and fiscal stimulus.

JEL Classification Numbers: O11

\section{INTRODUCTION}

After the accession of the countries of Central and Eastern Europe (CEE) to the European Union (EU), their market economies have been supported through the absorption of the European structural funds over the last decade, which improved their opportunities for attracting foreign investments and integration into international trade, and they became the fastest growing markets across the EU. Strong economic growth before the global financial crisis of 2008 and measures to tackle macroeconomic imbalances at European level have greatly reduced the vulnerability of these countries during the recession, making them an economically stable area in the EU.

With the help of the European structural funds, the CEE countries have started to move closer to the developed economies and move away from the other emerging markets in the European region, which is evidenced by the rapid growth of GDP per capita in terms of purchasing power parity, 9 percentage points for some countries like Bulgaria and Estonia

\footnotetext{
*Correspondence to: Iana Paliova PhD student,Economic Research Institute of Bulgarian Academy of Science, Address: Sofia 1504, Bulgaria, 12, Peter Delyan Str., Tel. +359 889 309 096, Email: ipaliova@imf.org
}

during the programming period 2007- 2013. Given the low level of GDP per capita for Bulgaria before the EU accession (38\% of the average GDP per capita in 2006), the aims for European funds absorption for boosting economic growth have been even more ambitious and important. The ex-post evaluation of the EC for the completed programming period 2007-2013 at the aggregate level justifies the conclusion of a very good return on the invested funds from the European structural funds, which confirms the conclusion of the successful process of convergence of the CEE countries. One euro from the cohesion policy instruments generated additional GDP of 2.74 euros, or 1 trillion additional GDP for all Member States.

The faster economic development of the CEE countries is rooted in the advantages of European integration and the impact of absorption of structural funds on aggregate demand, which is also confirmed by the empirical results of this paper.

The study consists of two parts: (a) the first part analyzes research on the multiplier effects of the European Structural Funds; b) the second part presents personal empirical estimates of the impact of absorption of EU structural funds on aggregate activity of CEE 
countries, based on the annual breakdown of the agreed European structural funds from countries of CEE by 2020 through the approach and assumptions of Rosenberg and Sierhej (2007) on the crowding out effects of the European structural funds' grant element (1).

\section{ANALYTICAL REVIEW OF RESEARCH ON THE MULTIPLIER EFFECTS OF EU STRUCTURAL FUNDS}

Many empirical studies based on econometric models for specific countries analyze and predict the impact of European funds on aggregate demand and potential economic growth in member states. The conclusions of the studies under consideration are not unambiguous, and the Member States have different outcomes. Most notable are Ireland and Greece, which become members of the EU in 1973 and 1981 respectively, but have a very different economic development and results in achieving economic and social cohesion with developed economies in the EU. In the year of accession, the two countries had similar GDP per capita compared with the average GDP per capita for the EU, respectively, 64\% in Ireland and 59\% in Greece. In 2015, Ireland has a GDP per capita of $177 \%$, while Greece is at a level of $68 \%$. One of the reasons for Greece's disappointing performance is the fiscal consolidation measures implemented to cope with the country's high indebtedness in recent years, but clearly the achieved by Greece in 2004 GDP per capita of $96 \%$ of the EU average level had not been stable, despite the long period of EU membership and absorption of structural funds. Barry et al. (2005) stresses in his study that only $0.5 \%$ of Ireland's annual growth rate of $8 \%$ during the 90 s is due to the EU funds, which means that Ireland has used effectively EU membership for successful transformation of its economy and has created a solid basis for long-term economic growth (2). Several studies highlight the importance of overall policy in the absorption of EU structural funds (Burnside and Dollar (2000), Hansen and Tarp (2000), Easterly (2003) (3$5)$.

Early empirical studies based on the EC's HERMIN model and applied to a separate recipient country point to the large positive effects of the structural funds spent on production and employment in long- and shortterm, as a typical Keynesian effect of increased public spending (Bradley and Fitzgerald, 1988; Bradley, Herce and Modesto, 1995). However, the results of the old member states show that their impact is not equal for all, and is not sustainable unless coupled with long-term national policies and priorities (6-7).

Estimates of the impact on aggregate activity from the use of the European structural funds also often ignore many of the possible adverse effects that may arise in practice and, to some extent, exaggerate it. Most preliminary simulations suggest well-functioning product and labor markets; efficient absorption of the structural funds; and a national contribution in addition to transfers from the European structural funds, i.e. the so-called "additionality principle" for the Structural Funds, which exaggerates their impact. Of the three prerequisites, only the principle of additionality is enshrined in the European regulations for the structural funds absorption, while the other two prerequisites depend on the degree of development of the economic and political system of the countries.

The increased public investment creates a relatively strong multiplier effect on demand, which is manifested in several areas, by financing public investment, including investment by state enterprises; by funding the development of human resources and professional skills, and through a range of funding measures to restructure businesses and improve their competitiveness (Lolos, 2001) (8). In addition to short-term effects on demand, long-term effects occur on supply, which has an impact on economic growth and investment. Long-term effects are created at the time of improving the productivity of the economy, but are revealed at a later stage after the completion of the programs of absorption. The EU funds absorption has long term effects and their impact is provoked by improving the productivity of various sectors through investments in physical and human capital. The calibration of data for Portugal by Pereira and Gasper (1999) showed that European structural funds contributed to an increase in economic growth by $0.5 \%$ per year and their impact on growth was optimal when they were used for infrastructure projects instead of physical and human capital (9). Other authors also believe that the greatest impact of EU funds is when they are used for investment rather than consumption (Boone, 1996) (10).

Some researchers are making estimates of the impact of the European structural funds on growth, similarly to foreign direct investment by countries and development aid for the restructuring of the economies of recipient countries. The conclusion is that not every use of European funds as an external financial resource generates genuine utility for the 
country. Moreover, at the end of each programming period of absorption of the Structural Funds, there is a risk of approving and implementing projects that are not so important to the economy to avoid losing funding that does not widen the boundaries of production opportunities, and even can create a future fiscal burden due to future maintenance costs. Thus, the increased aggregate demand from the Structural funds may hide structural inefficiencies and blur the need for overdue structural reforms. There are other potential problems related to the absorption of the European structural funds in recipient countries. Several factors contribute to the use of these funds for consumption rather than investment in physical and human capital. The problems may surge with the increase of funds and the inability of the countries to use them for the purposes of convergence (Herve and Holzmann, 1998) (11). As a basic instrument for implementing its cohesion policy, the European structural funds must achieve the standard of living in regional terms. However, studies indicate that small part of the economic growth in the regions is due to the projects financed by the Structural Funds (Boldrin and Canova, 2001), Tondl (1998), Fagerberg and Verspagen (1996) (12-14). Moreover, the European Structural Funds contribute to increasing economic growth and alignment of productivity and income in Europe, but the poorer regions are hampered by the unfavorable industrial structure, the dominant role of agriculture as a key sector and the lack of funds aimed at research and development (Cappelen et al., 2003) (15). Checherita, Nickel and Rother (2009) emphasize that while net transfers from the Structural Funds contribute to reducing disparities in household incomes at the regional level, they also hamper economic output (16). The latter is due to the negative impact of these transfers on the economic growth of the receiving regions and the negative impact on net taxes in the regions that provide the funds for these transfers. This does not bring about the necessary convergence, because economic growth in poorer regions is growing less than in the developed regions.

\section{EMPIRICAL ASSESSMENTS OF THE "CROWDING OUT" EFFECT OF ABSORPTION OF EUROPEAN STRUCTURAL FUNDS ON AGGREGATE DEMAND}

The agreed EU Structural Funds for the CEE countries for the 2007-13 and 2014-2020 programming periods are significant, and their breakdown by years depends on the joint partner countries' agreements with the European Commission. The average annual absorption rate of the funds in the CEE member states is between $1.5 \%$ and $3 \%$ of the GDP of the recipient country over the period 2007-2015 and around 3\% in the period 2014 2020 (Table 1).

Table 1. Contracted funds from the European Structural Funds by country, 2004 - 2020 (\% of GDP)

\begin{tabular}{|r|r|r|r|r|r|r|r|r|r|r|}
\hline & \multicolumn{1}{l}{ Bulgaria } & \multicolumn{1}{l}{$\begin{array}{l}\text { Czech } \\
\text { Republic }\end{array}$} & \multicolumn{1}{l}{ Estonia } & \multicolumn{1}{l}{ Hungary } & \multicolumn{1}{l}{ Latvia } & Lithuania & Poland & Romania & Slovakia & Slovenia \\
\hline 2004 & 0.0 & 0.2 & 0.6 & 0.2 & 0.6 & 0.5 & 0.4 & 0.0 & 0.0 & 0.0 \\
\hline 2005 & 0.0 & 0.2 & 0.7 & 0.4 & 0.9 & 0.8 & 0.3 & 0.0 & 0.0 & 0.0 \\
\hline 2006 & 0.0 & 0.4 & 1.0 & 0.7 & 0.8 & 0.8 & 0.7 & 0.0 & 0.0 & 0.0 \\
\hline 2007 & 1.5 & 2.8 & 3.2 & 3.7 & 3.7 & 4.1 & 3.7 & 1.0 & 3.1 & 1.8 \\
\hline 2008 & 1.9 & 2.5 & 3.3 & 3.6 & 3.5 & 3.7 & 3.2 & 1.2 & 2.7 & 1.7 \\
\hline 2009 & 2.5 & 2.2 & 2.9 & 3.3 & 2.9 & 3.0 & 2.7 & 1.9 & 2.2 & 1.5 \\
\hline 2010 & 2.5 & 2.2 & 2.9 & 3.3 & 3.2 & 3.1 & 2.3 & 2.2 & 2.2 & 1.5 \\
\hline 2011 & 2.4 & 2.1 & 2.8 & 3.3 & 3.1 & 2.9 & 2.3 & 2.2 & 2.2 & 1.5 \\
\hline 2012 & 2.5 & 2.2 & 2.8 & 3.5 & 2.9 & 2.9 & 2.3 & 2.3 & 2.3 & 1.5 \\
\hline 2013 & 2.6 & 2.3 & 2.8 & 3.5 & 3.0 & 2.9 & 2.4 & 2.2 & 2.3 & 1.5 \\
\hline 2014 & 3.1 & 2.1 & 2.8 & 3.2 & 2.9 & 2.4 & 2.7 & 2.5 & 2.7 & 1.4 \\
\hline 2015 & 3.7 & 2.4 & 3.4 & 3.8 & 3.7 & 2.9 & 3.2 & 3.1 & 3.2 & 1.7 \\
\hline 2016 & 3.7 & 2.1 & 2.7 & 3.4 & 2.8 & 2.3 & 2.5 & 2.5 & 3.1 & 1.7 \\
\hline 2017 & 3.6 & 2.3 & 3.3 & 4.1 & 3.6 & 2.9 & 3.4 & 3.0 & 3.1 & 1.6 \\
\hline 2018 & 3.5 & 2.3 & 3.3 & 4.0 & 3.5 & 2.8 & 3.3 & 2.9 & 3.1 & 1.6 \\
\hline 2019 & 3.5 & 2.3 & 3.2 & 3.9 & 3.4 & 2.7 & 3.2 & 2.8 & 3.0 & 1.6 \\
\hline 2020 & 3.4 & 2.3 & 2.3 & 3.8 & 3.3 & 2.0 & 2.3 & 2.7 & 2.9 & 1.5 \\
\hline
\end{tabular}

Source: European Commission (2016)

The grant element of the European Structural Funds has a significant impact on the macroeconomic activity of the CEE countries, and the results of this study prove one of the common hypotheses that increased public spending through European Structural Funds initially creates a relatively strong fiscal stimulus on demand. 
The assessments of Rosenberg and Sierhej (2007) for "crowding out" effect of absorption of EU funds on total production in CEE countries are used to assess their fiscal stimulus on aggregate demand. The coefficient for the "crowding out" of the European funding for the CEE countries, denoted by $\alpha$, depends on the varying degrees of substitution of the European funded projects towards national policies, and ranges between 0.55 (with a "crowing out" effect of $45 \%$ ) and 0.65 with a "crowding out" effect of $35 \%$ ). Following the additional requirements for the European Structural Funds, the EU project to be complemented by national projects (the principle of "additionality"), its contribution to aggregate demand could reach $100 \%$ and then the coefficient $\alpha$ to reach 1 , which implies a maximum impact on aggregate demand. Given that the European funds' advances are hardly used for European projects in the first years of the programming period due to the insufficient preparedness of the beneficiaries, they are excluded from the formula for assessing their impact on aggregate demand. The contribution of
I. PALIOVA

the countries to the EU budget is also excluded and the following equation is obtained:

$\mathrm{D}=\alpha(\mathrm{T}+\mathrm{NC})-\mathrm{C}-\mathrm{A} \mathrm{D}=\alpha(\mathrm{T}+\mathrm{NC})-\mathrm{C}-\mathrm{A}$

where:

D: impact on aggregate demand for all European Structural Funds (ESF) $\alpha$ : substitution between European and domestic funding; $\alpha$ ranges $[0 ; 1] ; \alpha=1$ (if there is no substitution)

T: transfers from ESF

A: advances received from ESF

NC: national co-financing

$\mathrm{C}$ : Contribution to the EU budget

The estimation based on the Rosenberg and Sierhej (2007) formula differs depending on the value of the crowding out factor $\alpha$ and changes between $0.3 \%$ to $2 \%$ at $\alpha$ values of 0.55 and 0.65 and reaches $2-3 \%$ for the value of a of 1 . The estimates suggest that it may reach cumulatively up to $10 \%$ of GDP at a $0.55 \%$ in 2015 (the last year of payments for projects for the 2007-13 programming period) $; 15 \%$ of GDP at a of 0.65 and $27 \%$ at $\alpha$ of 1 (Tables 2 - 4).

Table 2. Effects of ESF and other EU transactions on aggregate DSCF demand, 2004-2020 ( $\alpha=0.55)$

\begin{tabular}{|c|c|c|c|c|c|c|c|c|c|}
\hline Bulgaria & \begin{tabular}{|l|} 
Czech \\
Republic \\
\end{tabular} & Estonia & Hungary & Latvia & Lithuania & Poland & Romania & Slovakia & Slovenia \\
\hline & -0.9 & -0.8 & -0.9 & -0.8 & -0.8 & -0.8 & & -1.0 & -1.0 \\
\hline & -0.9 & -0.8 & -0.9 & -0.7 & -0.7 & -0.9 & & -1.0 & -1.0 \\
\hline & -0.9 & -0.6 & -0.8 & -0.7 & -0.7 & -0.8 & & -1.0 & -1.0 \\
\hline-0.2 & 0.3 & 0.3 & 0.6 & 0.3 & 0.5 & 0.5 & -0.4 & 0.1 & -0.1 \\
\hline-0.1 & 0.1 & 0.4 & 0.5 & 0.2 & 0.6 & 0.3 & -0.3 & 0.0 & -0.2 \\
\hline 0.0 & 0.7 & 0.9 & 1.3 & 0.4 & 1.0 & 0.9 & -0.3 & -0.2 & 0.0 \\
\hline 0.8 & 0.6 & 1.1 & 1.3 & 0.9 & 1.2 & 0.6 & 0.6 & 0.5 & 0.1 \\
\hline 0.7 & 0.5 & 1.0 & 1.3 & 0.7 & 1.0 & 0.7 & 0.6 & 0.5 & 0.1 \\
\hline 0.7 & 0.6 & 1.0 & 1.4 & 0.6 & 1.1 & 0.6 & 0.5 & 0.5 & 0.1 \\
\hline 0.7 & 0.6 & 0.8 & 1.4 & 0.5 & 1.0 & 0.6 & 0.5 & 0.5 & 0.0 \\
\hline 1.0 & 0.4 & 0.8 & 1.1 & 0.9 & 0.6 & 0.8 & 0.7 & 0.8 & -0.1 \\
\hline 1.4 & 0.6 & 1.2 & 1.5 & 1.4 & 0.9 & 1.1 & 1.0 & 1.1 & 0.1 \\
\hline 1.4 & 0.4 & 0.8 & 1.3 & 0.9 & 0.5 & 0.7 & 0.6 & 1.1 & 0.1 \\
\hline 1.4 & 0.5 & 1.2 & 1.7 & 1.4 & 0.9 & 1.2 & 1.0 & 1.0 & 0.1 \\
\hline 1.3 & 0.5 & 1.2 & 1.6 & 1.3 & 0.9 & 1.2 & 0.9 & 1.0 & 0.1 \\
\hline 1.3 & 0.5 & 1.1 & 1.6 & 1.2 & 0.8 & 1.1 & 0.9 & 1.0 & 0.0 \\
\hline 1.2 & 0.5 & 0.5 & 1.5 & 1.2 & 0.3 & 0.5 & 0.8 & 0.9 & 0.5 \\
\hline
\end{tabular}

Table 3. Effects of ESF and other EU transactions on aggregate DSCF demand, 2004-2020 ( $\alpha=0.65)$

\begin{tabular}{|c|c|c|c|c|c|c|c|c|c|}
\hline Bulgaria & \begin{tabular}{|l|} 
Czech \\
Republic
\end{tabular} & Estonia & Hungary & Latvia & Lithuania & Poland & Romania & Slovakia & Slovenia \\
\hline & -0.9 & -0.7 & -0.9 & -0.7 & -0.8 & -0.8 & & -1.0 & -1.0 \\
\hline & -0.9 & -0.7 & -0.8 & -0.6 & -0.6 & -0.8 & & -1.0 & -1.0 \\
\hline & -0.8 & -0.5 & -0.7 & -0.6 & -0.6 & -0.7 & & -1.0 & -1.0 \\
\hline 0.0 & 0.6 & 0.7 & 1.0 & 0.8 & 1.0 & 1.0 & -0.3 & 0.5 & 0.1 \\
\hline 0.1 & 0.4 & 0.8 & 0.9 & 0.6 & 1.0 & 0.7 & -0.1 & 0.3 & 0.0 \\
\hline 0.3 & 0.9 & 1.3 & 1.7 & 0.8 & 1.3 & 1.2 & -0.1 & 0.0 & 0.2 \\
\hline 1.1 & 0.9 & 1.4 & 1.7 & 1.3 & 1.5 & 0.9 & 0.9 & 0.7 & 0.3 \\
\hline 1.0 & 0.8 & 1.4 & 1.7 & 1.1 & 1.4 & 1.0 & 0.9 & 0.7 & 0.3 \\
\hline 1.0 & 0.9 & 1.3 & 1.9 & 1.0 & 1.5 & 0.9 & 0.8 & 0.8 & 0.2 \\
\hline 1.0 & 0.9 & 1.2 & 1.8 & 0.8 & 1.4 & 0.9 & 0.8 & 0.8 & 0.2 \\
\hline 1.4 & 0.6 & 1.2 & 1.5 & 1.3 & 0.8 & 1.1 & 1.0 & 1.1 & 0.1 \\
\hline 1.9 & 0.8 & 1.6 & 2.0 & 1.9 & 1.3 & 1.5 & 1.4 & 1.5 & 0.3 \\
\hline 1.9 & 0.6 & 1.1 & 1.7 & 1.2 & 0.8 & 1.0 & 0.9 & 1.4 & 0.3 \\
\hline 1.8 & 0.8 & 1.6 & 2.2 & 1.8 & 1.2 & 1.6 & 1.3 & 1.4 & 0.3 \\
\hline 1.8 & 0.8 & 1.6 & 2.1 & 1.7 & 1.2 & 1.6 & 1.3 & 1.4 & 0.2 \\
\hline 1.7 & 0.8 & 1.5 & 2.0 & 1.6 & 1.1 & 1.5 & 1.2 & 1.3 & 0.2 \\
\hline 1.6 & 0.8 & 0.8 & 2.0 & 1.6 & 0.5 & 0.8 & 1.1 & 1.3 & 0.8 \\
\hline
\end{tabular}

Source: own calculations, European Commission 
Table 4. Effects of ESF and other EU transactions on aggregate DSCF demand, 2004-2020 $(\alpha=1)$

\begin{tabular}{|c|c|c|c|c|c|c|c|c|c|}
\hline Bulgaria & \begin{tabular}{|l|} 
Czech \\
Republic
\end{tabular} & Estonia & Hungary & Latvia & Lithuania & Poland & Romania & Slovakia & Slovenia \\
\hline & -0.8 & -0.5 & -0.8 & -0.4 & -0.5 & -0.6 & & -1.0 & -1.0 \\
\hline & -0.8 & -0.4 & -0.6 & -0.2 & -0.3 & -0.7 & & -1.0 & -1.0 \\
\hline & -0.7 & -0.1 & -0.4 & -0.2 & -0.3 & -0.4 & & -1.0 & -1.0 \\
\hline 0.7 & 1.8 & 2.1 & 2.5 & 2.3 & 2.7 & 2.5 & 0.2 & 1.7 & 0.9 \\
\hline 0.9 & 1.5 & 2.2 & 2.4 & 2.1 & 2.6 & 2.1 & 0.4 & 1.5 & 0.7 \\
\hline 1.3 & 1.9 & 2.5 & 3.1 & 2.0 & 2.6 & 2.3 & 0.7 & 1.0 & 0.8 \\
\hline 2.2 & 1.8 & 2.7 & 3.1 & 2.6 & 2.8 & 1.9 & 1.8 & 1.6 & 0.9 \\
\hline 2.1 & 1.7 & 2.6 & 3.1 & 2.4 & 2.6 & 1.9 & 1.8 & 1.7 & 0.9 \\
\hline 2.1 & 1.8 & 2.5 & 3.3 & 2.2 & 2.7 & 1.9 & 1.8 & 1.7 & 0.9 \\
\hline 2.1 & 1.8 & 2.4 & 3.3 & 2.1 & 2.6 & 1.9 & 1.7 & 1.7 & 0.8 \\
\hline 2.7 & 1.5 & 2.3 & 2.9 & 2.5 & 1.8 & 2.2 & 2.0 & 2.2 & 0.7 \\
\hline 3.4 & 1.8 & 3.1 & 3.6 & 3.4 & 2.5 & 2.8 & 2.7 & 2.8 & 1.0 \\
\hline 3.4 & 1.5 & 2.3 & 3.1 & 2.4 & 1.7 & 2.0 & 2.0 & 2.8 & 1.0 \\
\hline 3.3 & 1.8 & 3.0 & 3.9 & 3.3 & 2.5 & 3.0 & 2.6 & 2.7 & 1.0 \\
\hline 3.3 & 1.7 & 2.9 & 3.8 & 3.2 & 2.4 & 3.0 & 2.5 & 2.7 & 0.9 \\
\hline 3.2 & 1.8 & 2.9 & 3.7 & 3.1 & 2.3 & 2.9 & 2.4 & 2.6 & 0.9 \\
\hline 3.1 & 1.8 & 1.8 & 3.6 & 2.9 & 1.4 & 1.8 & 2.3 & 2.5 & 1.7 \\
\hline
\end{tabular}

Source: own calculations, European Commission

Empirical studies on the impact of EU funds devoted to CEE countries are comparable to those for the old member states. Allard and others (2008) using the Global Integrated Monetary and Fiscal model of IMF (GIMF) assess the impact of structural funds for new member states as a group in terms of the EU15 as donor countries (17). Their conclusion is that investments in the public sector have the most permanent impact about 3 percent higher than the baseline scenario, mainly because the private capital depreciation is assumed to be higher than in the public sector. GIMF calibrated to Bulgaria also predicted that the implementation of structural funds could increase GDP by $1.5-3 \%$ annually in the medium term (Muir and Weber, 2012; Paliova and Lybek, 2014) (18-19).

Econometric estimates for the improvement of physical infrastructure and human capital and acceleration of economic growth and convergence based on the HERMIN model of the European Commission show higher GDP than the baseline scenario for the Czech Republic (4.4\%), Hungary (4.1\%), Estonia (3.7 Poland (2.7\%), Romania (1.7\%) and Latvia (1.4\%). Bradley and Morgenroth (2004) however consider that the CEE convergence would be achieved relatively slowly due to their lower level of GDP per capita between $35 \%$ and $55 \%$ compared to the EU average GDP at the accession (20). The progress made by the CEE countries for the 2007-2013 programming period shows that in most of them the GDP growth per capita is about 8-9 percentage points, which contradicts this conclusion. Varga and Veld (2010) use the EC model for all member states, with estimates for
CEE countries as well as for Bulgaria showing an increase in GDP to $3 \%$ on an annual basis in the medium term (21). Gáková et al (2009) use the more traditional macro model of EC HERMIN and conclude that GDP will increase by about $3.6 \%$ during the implementation period when fully absorbed initially planned (22). The econometric model SIBILA (Tsvetkov, Vassilev, Ganev, Ganeva and Chobanov, 2011) of the Bulgarian government assesses the impact on economic growth in Bulgaria of the Structural funds for the 20072013 programming period, depending on the extent of their absorption to be up to $9 \%$ over the baseline scenario (23). The assessment of the Bulgarian Academy of Sciences (2015) is for an annual contribution to potential growth of more than $0.4 \%$ after 2012 and over $0.6 \%$ in 2014 (24).

Figure 1 shows the country-by-country impact of the European Structural Funds on the aggregated economic activity for each country separately. For example, estimates in this study for the Czech Republic and Hungary are like those of Varga and Velt (2010) in the range between $1 \%-2 \%$ and $1.5 \%-4 \%$ respectively.

Estimates vary depending on the approach or model, which is used, but they all show that in the short term, projects funded by the European Structural Funds and co-funded by recipient countries stimulate domestic demand, mainly through public sector investments, but also through goods and services. In the long run, the European funding as an external growth factor rises potential growth by increasing gross capital formation. On the other hand, to properly evaluate the impact on 
aggregate demand, expert assessments are also very important, as models often ignore many of the possible adverse effects that may arise in practice and to some extent are exaggerated.
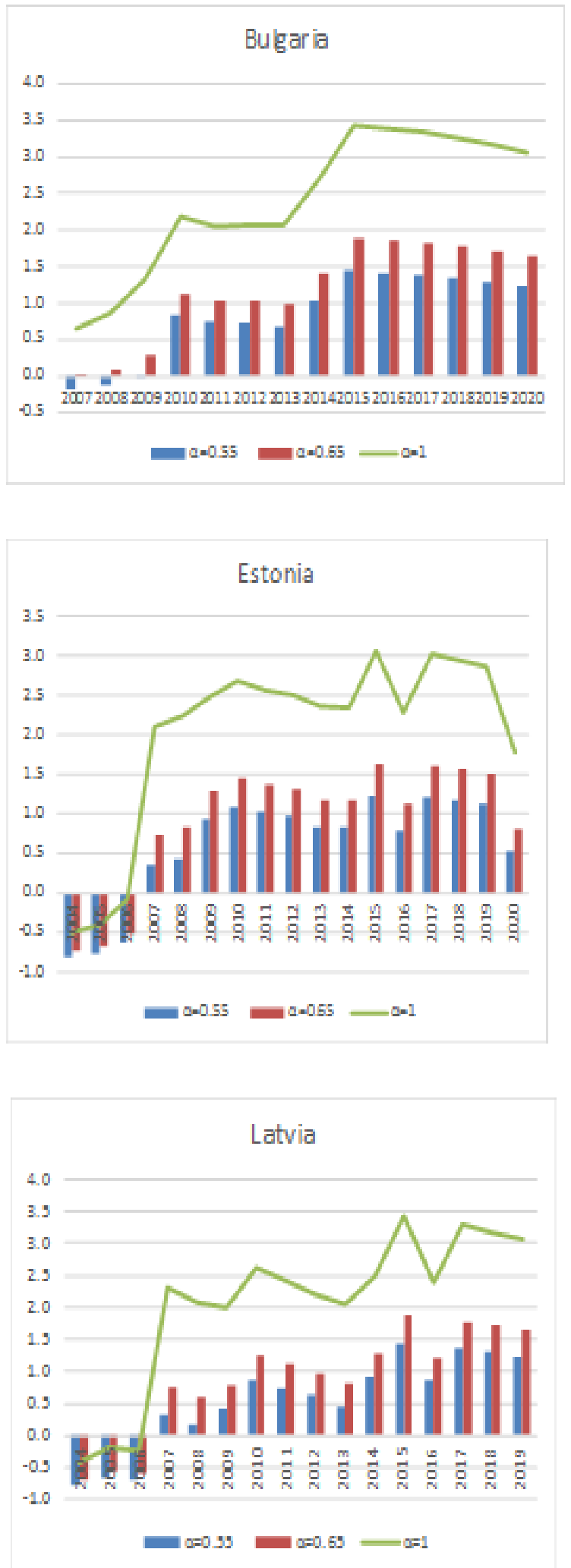

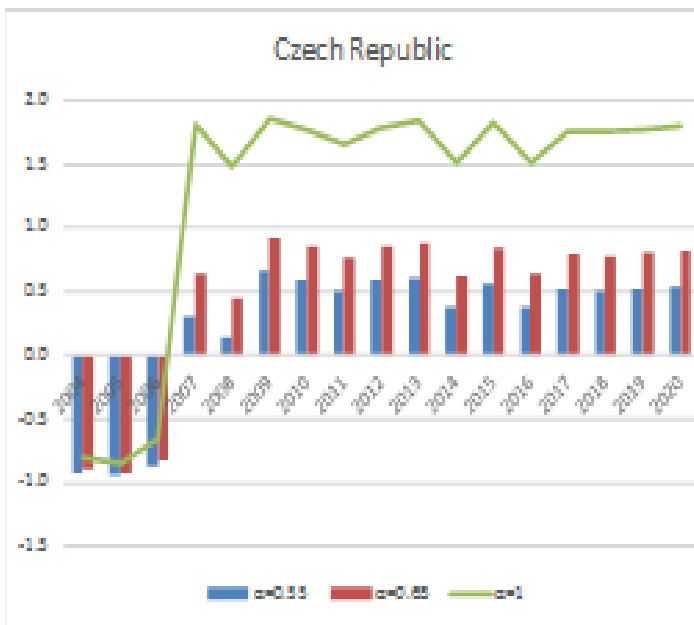

Hungary

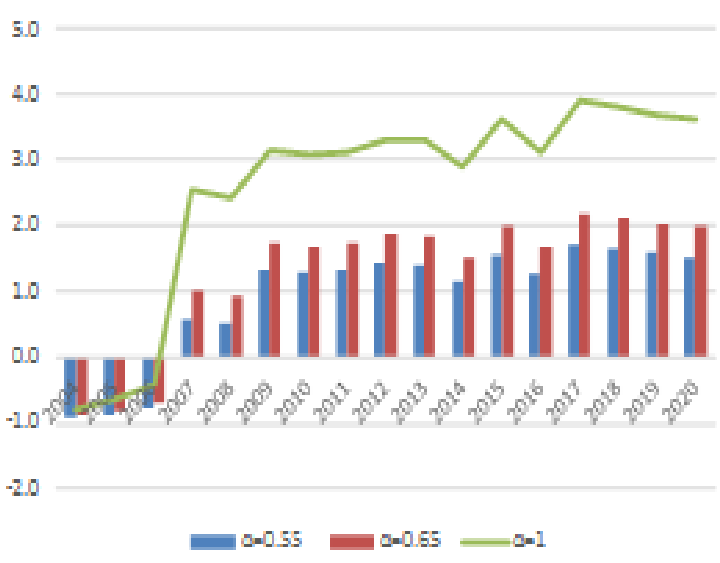

Lithuania

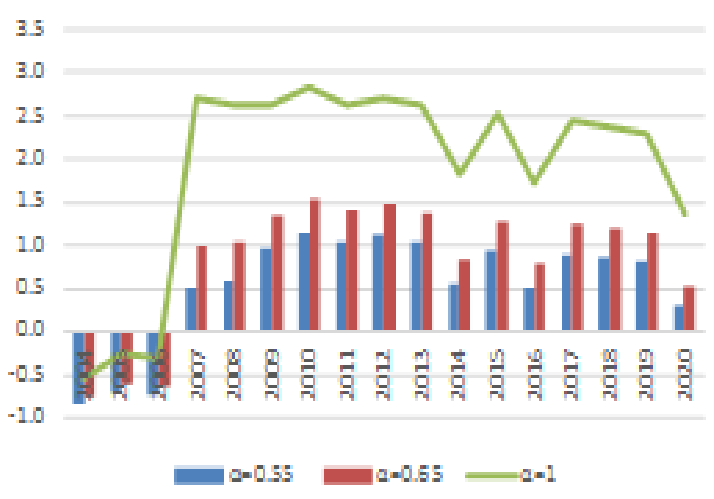



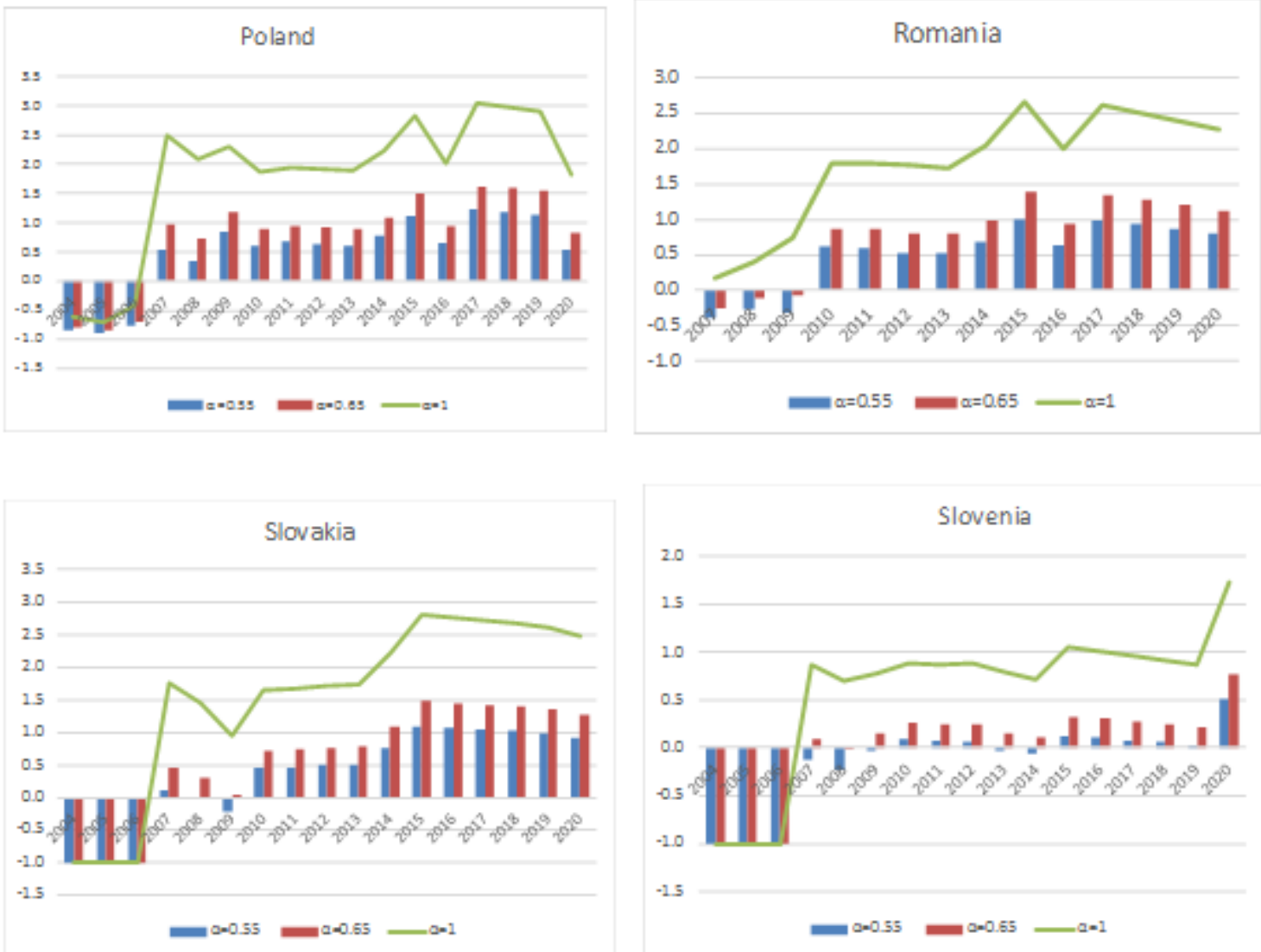

Figure 1. CEE countries: Effects of European Structural Funds and other EU transactions on aggregate demand, 2004-2020 (in\% of GDP)

Source: Own calculations, Rosenberg and Sierhej formula (2007), Eurostat (2016)

\section{CONCLUSION}

Estimates generally confirm the main findings in other economic studies in the field of fiscal and the macroeconomic effects of the European Structural Funds on economic activity during different periods of the business cycle.

They testify to the fact that the grant element of the European Structural Funds reduces the financial limit compared to the standard fiscal stimulus, but at the same time they can be a fiscal stimulus, especially in times when the economy is below its potential growth in the downward phase of the business cycle.

The empirical results of this study show unconditionally that European Structural Funds in the CEE countries can be a very useful tool for stimulating economic activity and optimizing economic growth. In principle, the stimulating effect of EU SCF absorption on aggregate demand is not only additional but also necessary to bring those countries closer together with older EU Member States.
The estimates suggest that the impact of European Funds on economic activity may range between $1.5 \%$ and $3 \%$ of the GDP of the

CEE countries, depending on the "crowding out" factor of replacing European funded and nationally funded projects. They also suggest that the impact could reach cumulatively up to $10 \%$ of GDP at $\alpha$ rate of 0.55 in 2015 (the last year of payments under the 2007-2013 programming period), $15 \%$ of GDP at $\alpha$ of 0.65 and $27 \%$ at $\alpha$ of 1 .

At the same time, assessments often ignore many of the possible adverse effects that may arise in practice and to some extent are exaggerated. Moreover, the increased aggregate demand from the European Structural Funds may hide structural inefficiencies and blur the need for overdue structural reforms. Achieving beneficial effects therefore requires effective institutions, low levels of corruption, good co-operation of all actors in the process, and fully prepared EUfunded projects to be adequately applied to the business cycle. 


\section{REFERENCES}

1. Rosenberg, Christoph B. and Robert Sierhej, 2007, "Interpreting EU Funds Data for Macroeconomic Analysis in the New Member States", IMF Working Paper WP/07/77, International Monetary Fund, Washington DC

2. Barry F., Hannan A., Hutson E. , Kearney C., 2005, Competitiveness Implications for Ireland of EU Enlargement, Institute for International Integration Studies, Discussion Paper, 49 January, Trinity College Dublin, Ireland

3. Burnside C., Dollar D., 2000, "Aid, Policies, and Growth ", The American Economic Review Vol. Vol. 90, No. 90, No. 4 (Sep., 2000), pp. 4 (Sep., 2000), pp. 847-868 847868

4. Hansen H., Tarp F., 2000, "Aid and Growth Regressions", University of Nottingham

5. Easterly W., 2003, "Can Foreign Aid Buy Growth? ", The Journal of Economic Perspectives Vol. Vol. 17, No. 17, No. 3 (Summer, 2003), pp. 3 (Summer, 2003), pp. 23-48 23-48

6. Bradley J., Fitzgerald J., 1988, Industrial Output and Factor Input determination in an Econometric Model of a Small Open Economy ", European Economic Review, 32, pp. 1227-41

7. Bradley J., Herce J., Modesto L., 1995, Modeling in the EU periphery, the HERMIN project ", Economic Modeling, special edition, 12 (3)

8. Lolos S., 2001, "The Macroeconomic Effect of EU Structural Transfers on the Cohesion Countries and Lessons for the CEECs," Interim Report No. IR-01-044 (October), International Institute for Applied Systems Analysis: Austria.

9. Pereira, A., Gaspar V. (1999) "An Intertemporal Analysis of Development Policies in the EU", Journal of Policy Modelling, 21 (7), 799-822.

10. Boone P., 1996, Politics and the effectiveness of Foreign Aid, Discussion Paper 272, London School of Economics

11.Herve Y., Holzmann R., 1998, Fiscal Transfers and Economic Convergence in the EU: An Analysis of Absorption Problems and the Evaluation of the Literature, BadenBaden, Germany: Nomos

12.Boldrin M., Canova $\mathrm{K}$.: Inequality and convergence in Europe's regions: reconsidering European region- al policies, in: Economic Policy, No. 32, 2001, pp. 207253.

13. Tondl G., 1998, The Changing Pattern of Regional Convergence in Europe, Robert Schuman Centre (EUI), RSC No. 97/53
14.Fagerberg, J. and Verspagen, B, 1996, "Heading for Divergence? Regional Growth in Europe Reconsidered ", Journal of Common Market Studies, 34 (3): 431-448

15. Cappelen A., Castellacci F., Fagerberg J. , Verspagen B., 2003, "The Impact of EU Regional Support on Growth and Convergence in the European Union", JCMS: Journal of Common Market Studies, Volume 41, Issue 4, Pages 621-644, September 2003

16. Checherita C., Nickel C., Rother P., 2009, "The role of fiscal transfers for regional economic convergence in Europe", ECB Working Paper No. 1029

17. Allard, Celine; Nada Choueiri; Susan Schadler; and Rachel van Elkan, 2008, "Macroeconomic Effects of EU Transfers in New Member States," IMF Working Paper WP/08/223, International Monetary Fund, Washington DC

18.Paliova I. and Lybek T., 2014, Bulgaria's EU Funds Absorption: Maximizing the Potential!, , IMF Working Paper No. 14/21.

19. Muir, Dirk and Anke Weber, 2013, "Fiscal Multipliers in Bulgaria: Low but Still Relevant," IMF Working Paper WP/13/49, International Monetary Fund, Washington DC.

20. Bradley J., Morgenroth E., 2004, "A Study of the Macroeconomic Impact of the Reform of EU Cohesion Policy", Economic and Social Research Institute, Dublin, Ireland

21.Varga, J., in 't Veld, 2010, "The Potential Impact of EU Cohesion Spending in the 2007-13 Programming Period: A ModelBased Analysis", European Economy Economic Paper, No. 422, Brussels.

22. Gáková, Z.; Dalia Grigonyte; Philippe Monfort, 2009, “A Cross-Country Impact Assessment of EU Cohesion Policy: Applying the Cohesion System of HERMIN Models", European Union Working Regional Policy Working Papers No. 1, European Commission, Brussels.

23. Tsvetkov, Vassilev, Ganev, Ganeva and Chobanov, 2011, SIBILA model was developed by a European project № 0018CIO-3.2 "Development of a model for impact assessment of SCF" financed by the Operational Program "Technical Assistance"

24. Annual Report of the Bulgarian Academy of Sciences in 2015, Economic Development and Policies in Bulgaria: estimates and expectations, the Spotlight: "Policies for economic development in the operational programs and the common agricultural policy in the period 2007 -2013 g», https: // Www.iki.bas.bg/godishen-doclad-2015 